\title{
Uterine Histone Secretion Likely Fosters Early Embryo Development So Efforts to Mitigate Histone Cytotoxicity Should Be Cautious
}

\author{
Lon J. Van Winkle ${ }^{1,2 *}$ \\ ${ }^{1}$ Department of Biochemistry, Midwestern University, Downers Grove, IL, United States, ${ }^{2}$ Department of Medical Humanities, \\ Rocky Vista University, Parker, CO, United States
}

Keywords: histones, blastocyst, implantation, antimicrobial, early development, amino acid transport systems

\section{INTRODUCTION}

The possible benefits of mitigating extracellular histone cytotoxicity have been outlined for the reproductive tract and other organs (e.g., Simon et al., 2013; Galuska et al., 2017; Lefrançais and Looney, 2017; Wygrecka et al., 2017; Yang et al., 2017). However, a reassessment of previously published data supports the notion that uterine histone secretion fosters early embryo development in multiple ways. (See below.) Hence, efforts to neutralize extracellular histone action in reproductive organs should be cautious. Thus far, there appears to be little discussion of how

Edited by:

Karin Lykke-Hartmann, Aarhus University, Denmark

Reviewed by:

Shuo Xiao,

University of South Carolina,

United States

${ }^{*}$ Correspondence:

Lon J. Van Winkle

Ivanwinkle@rvu.edu

Specialty section:

This article was submitted to

Signaling,

a section of the journa

Frontiers in Cell and Developmental

Biology

Received: 02 July 2017 Accepted: 13 November 2017

Published: 27 November 2017

Citation:

Van Winkle LJ (2017) Uterine Histone Secretion Likely Fosters Early Embryo

Development So Efforts to Mitigate Histone Cytotoxicity Should Be Cautious. Front. Cell Dev. Biol. 5:100. doi: 10.3389/fcell.2017.00100 to preserve desirable histone effects while mitigating pathology caused by excessive extracellular histone actions.

\section{MECHANISMS OF HISTONE CYTOTOXICITY ARE LIKELY RELATED TO THEIR ANTIMICROBIAL EFFECTS}

Histones contribute to eukaryotic chromatin structure and function in a well-known manner (e.g., Harr et al., 2016). Less well known are the extra-nuclear functions of these macromolecules (e.g., Parseghian and Luhrs, 2006). Among these other functions, extracellular histones fight bacterial, fungal, viral, and other parasitic infections (Papayannopoulos, in press). At least two distinct mechanisms account for these antimicrobial effects.

First, histones are essential components of neutrophil extracellular traps (NETs). NETs are netlike structures that form from decondensed chromatin and cytosolic proteins. They usually form when neutrophils undergo cell death via a process termed NETosis. NETs trap and kill each of the pathogens listed above (Papayannopoulos, in press).

Free histones also have antimicrobial functions (Kawasaki and Iwamuro, 2008). For example, histones in amniotic fluid appear to fight bacteria by neutralizing the lipopolysaccharide (LPS) of microbes that gain access to this fluid (Witkin et al., 2011). Without such protection, LPS could cause pre-term labor and delivery (Hirsch et al., 2006).

The cytotoxic effects of histones are likely related to their mechanisms of antimicrobial action. For example, the hyperinflammatory response and death of mice given high doses of LPS appear to require free histones. Moreover, administration of free histones to mice causes their death (Xu et al., 2009). Similarly, histones contribute to organ damage by excessive NETosis especially in lungs (Silk et al., 2017; Papayannopoulos, in press). Clearly, NETosis and the actions of free histones need tight regulation in order to benefit mammals and prevent pathological effects. 


\section{ANTIMICROBIAL ACTIONS OF HISTONES IN THE REPRODUCTIVE TRACT}

Extracellular histones also help to inhibit microbial proliferation in the reproductive tract. For example, in a mouse model, NETs appear to limit Group B Streptococcal infection via the vagina during pregnancy (Kothary et al., 2017). In addition, free histones in fluids from the reproductive tract of cows exhibit antimicrobial actions (Dráb et al., 2014). Since pathogens can cause inflammation in the reproductive tract of mammals, they can also adversely affect mammalian reproduction (Wiesenfeld et al., 2002; Mårdh, 2004; BonDurant, 2007). While extracellular histones protect against microbes in at least two ways, only one of these mechanisms of action likely apply to free histone molecules in follicular, oviductal, and uterine secretions.

\section{DIRECT CONTRIBUTION OF HISTONES TO EARLY EMBRYO DEVELOPMENT}

\section{Background}

Histones appear most abundantly in human uterine secretions at the time the uterus is receptive to blastocyst implantation (Beier and Beier-Hellwig, 1998). Similarly, histones are synthesized at increased rates in the uterine epithelium and stroma of ovariectomized mice upon administration of a hormonal protocol known to result in blastocyst implantation about $25 \mathrm{~h}$ later (Smith et al., 1970). Assuming histones appear in mouse uterine fluid when the uterus becomes receptive to blastocyst implantation, what other functions might histones serve there? One good possibility involves amino acid transport system $\mathrm{B}^{0,+}$ in mouse and probably human blastocysts (Van Winkle et al., 2006). In order to consider this possibility in context, we first review system $\mathrm{B}^{0,+}$ involvement in early embryo development and blastocyst implantation in the uterus.

The process of blastocyst implantation in the mouse is especially amenable to study owing to experimentally-controlled delay of implantation. While delay of implantation (diapause) occurs naturally in mice when blastocysts develop in nursing mothers, it can be produced experimentally in mice by removing their ovaries about $76 \mathrm{~h}$ after their eggs have been fertilized (Van Winkle and Campione, 1987; Van Winkle et al., 2006). Daily administration of progesterone followed by estrogen on day 7 of pregnancy then leads to blastocyst implantation $25 \mathrm{~h}$ later.

During this activation from delay of implantation, signaling owing to leucine uptake via amino acid transport system $\mathrm{B}^{0,+}$ results specifically in development of trophoblast motility and penetration of the uterine epithelium by blastocysts (Van Winkle et al., 2006). This signaling occurs because increases in the $\mathrm{Na}^{+}$and $\mathrm{K}^{+}$concentrations in uterine secretions about $6 \mathrm{~h}$ after estrogen administration to ovariectomized, progesteronetreated rodents (Van Winkle et al., 1983; Nilsson and Ljung, 1985) drive net $\mathrm{Na}^{+}$-dependent system $\mathrm{B}^{0,+}$ leucine uptake by the blastocyst trophectoderm. Leucine then stimulates the mTOR signaling that is needed for development of trophoblast motility and penetration of the uterine epithelium, which occur about $19 \mathrm{~h}$ later (Van Winkle et al., 2006). Meanwhile the uterine environment somehow suppresses system $\mathrm{B}^{0,+}$ activity beginning about $10 \mathrm{~h}$ after estrogen administration (Lindqvist et al., 1978; Van Winkle and Campione, 1987). For example, blastocysts take up a radiolabeled, nonmetabolizable amino acid in utero, when it is administered to their mothers about $6 \mathrm{~h}$ after estrogen administration, but little or no uptake occurs when the amino acid is administered $4 \mathrm{~h}$ before or after this time (Lindqvist et al., 1978). We calculated that the decrease, in the rate of amino acid uptake between about 6 and $10 \mathrm{~h}$ after estrogen administration, is statistically equivalent to finding a drug that lowers the death rate from 94 to $6 \%$ (based on the effect size that can be calculated from the data of Lindqvist et al., 1978). At the time of the latter report, however, the full physiological significance of these changes in amino acid uptake by blastocysts in utero were not understood.

Although system $\mathrm{B}^{0,+}$ is relatively inactive in utero during the $15 \mathrm{~h}$ prior to blastocyst implantation, it can be reactivated to even greater levels of transport activity simply by removing blastocysts from the uterus near the time of blastocyst implantation (Van Winkle and Campione, 1987). This ability to reactivate system $\mathrm{B}^{0,+}$ activity also likely serves an important physiological function (Van Winkle et al., 2006). After reactivation, system $\mathrm{B}^{0,+}$ would help to remove tryptophan from the implantation chamber during the initial penetration of the uterus by motile trophoblasts and, thus, help to suppress T-cell proliferation and immunologic rejection of the blastocyst (Munn et al., 1998; Baban et al., 2004).

\section{Possible Histone Involvement}

But what reversibly suppresses system $\mathrm{B}^{0,+}$ activity beginning about $15 \mathrm{~h}$ before blastocyst implantation? Good candidates include histones that are likely secreted by uterine epithelial and possibly stromal cells when the uterus becomes receptive to blastocyst attachment and penetration (Smith et al., 1970). At near the histone concentrations detected in uterine fluid (Beier and Beier-Hellwig, 1998; Dráb et al., 2014), we found these macromolecules to inhibit amino acid uptake by mouse blastocysts. System $\mathrm{B}^{0,+}$ activity, in particular, was inhibited much more than the activities of several other amino acid transport systems in blastocysts (Table IV in Van Winkle, 1993). In fact, the extent to which histones inhibited each of four different amino acid transport systems in blasocysts, differed from each other $(p<0.02)$, and ranged from near $90 \%$ inhibition of system $\mathrm{B}^{0,+}$ to no inhibition of system L. Hence, it seems unlikely that histone cytotoxicity alone caused histone inhibition of amino acid transport system $\mathrm{B}^{0,+}$ activity in blastocysts.

Perhaps not coincidentally, the effect size of this system $\mathrm{B}^{0,+}$ inhibition by histones equals the effect size reported above, for reduction of the rate of amino acid transport into blastocysts in utero between about 6 and $10 \mathrm{~h}$ after estrogen administration to progesterone-maintained ovariectomized mice (Lindqvist et al., 1978). In addition, histone H2A (one of the more conspicuous histones in secretions of the receptive human uterus; Beier and Beier-Hellwig, 1998) likely is more effective at inhibiting amino acid uptake by blastocysts than other histones (Doman and Van Winkle, 1979). Reactivation of system $\mathrm{B}^{0,+}$ in blastocysts, at the time of blastocyst penetration of the uterine epithelium, could be accomplished simply by removing histones from the relatively small amount of uterine fluid in implantation chambers. In this regard, proteases, needed to hydrolyze histones to inactive 
products, appear to abound in these chambers (e.g., Afonso et al., 1997).

While it is unclear why system $\mathrm{B}^{0,+}$ activity needs to be suppressed after mTOR signaling, we observed one tantalizing possibility. When we incubated delayed-implantation blastocysts for $25 \mathrm{~h}$ in vitro in medium containing a relatively high $\mathrm{Na}^{+}$concentration, they irreversibly lost their $\mathrm{Na}^{+}$-dependent component of amino acid uptake (Van Winkle, 1977). This apparent loss of $\mathrm{Na}^{+}$-dependent system $\mathrm{B}^{0,+}$ activity would likely mean that the ability of blastocysts to activate net $\mathrm{Na}^{+}$dependent tryptophan uptake would also be lost. If such loss were to occur in the implantation chamber in utero, then implanting blastocysts could face immunological rejection. Hence, suppression of system $\mathrm{B}^{0,+}$ in blastocysts by histones after initiation of mTOR signaling, could preserve this activity for activation and concentration of tryptophan into trophoblast cells at the time of trophoblast penetration of the uterine epithelium.

\section{CONCLUSIONS}

We propose here that extracellular histones have at least two somewhat surprising functions during early development of blastocysts and their implantation in the uterus. First, free

\section{REFERENCES}

Afonso, S., Romagnano, L., and Babiarz, B. (1997). The expression and function of cystatin $\mathrm{C}$ and cathepsin $\mathrm{B}$ and cathepsin $\mathrm{L}$ during mouse embryo implantation and placentation. Development 124, 3415-3425.

Baban, B., Chandler, P., McCool, D., Marshall, B., Munn, D. H., and Mellor, A. L. (2004). Indoleamine 2, 3-dioxygenase expression is restricted to fetal trophoblast giant cells during murine gestation and is maternal genome specific. J. Reprod. Immunol. 61, 67-77. doi: 10.1016/j.jri.2003.11.003

Beier, H. M., and Beier-Hellwig, K. (1998). Molecular and cellular aspects of endometrial receptivity. Hum. Reprod. Update 4, 448-458. doi: 10.1093/humupd/4.5.448

BonDurant, R. H. (2007). Selected diseases and conditions associated with bovine conceptus loss in the first trimester. Theriogenology 68, 461-473. doi: 10.1016/j.theriogenology.2007.04.022

Doman, D. R., and Van Winkle, L. J. (1979). A histone induced diminution of ${ }^{14} \mathrm{C}$ amino acid uptake and incorporation in preimplantation mouse embryos. Bios $50,67-73$.

Dráb, T., Kračmerová, J., Hanzlíková, E., Cerná, T., Litváková, R., Pohlová, A., et al. (2014). The antimicrobial action of histones in the reproductive tract of cow. Biochem. Biophys. Res. Commun. 443, 987-990. doi: 10.1016/j.bbrc.2013. 12.077

Galuska, S. P., Galuska, C. E., Tharmalingam, T., Zlatina, K., Prem, G., Husejnov, F. C., et al. (2017). In vitro generation of polysialylated cervical mucins by bacterial polysialyltransferases to counteract cytotoxicity of extracellular histones. FEBS J. 284, 1688-1699. doi: 10.1111/febs.14073

Harr, J. C., Gonzalez-Sandoval, A., and Gasser, S. M. (2016). Histones and histone modifications in perinuclear chromatin anchoring: from yeast to man. $E M B O$ Rep. 17, 139-155. doi: 10.15252/embr.201541809

Hirsch, E., Filipovich, Y., and Mahendroo, M. (2006). Signaling via the type I IL-1 and TNF receptors is necessary for bacterially induced preterm labor in a murine model. Am. J. Obstet. Gynecol. 194, 1334-1340. doi: $10.1016 /$ j.ajog.2005.11.004

Kawasaki, H., and Iwamuro, S. (2008). Potential roles of histones in host defense as antimicrobial agents. Infect. Disord. Drug Targets 8, 195-205. doi: $10.2174 / 1871526510808030195$ histones protect blastocysts and the uterus from the adverse effects of unwanted inflammation caused by infection. Histones appear in abundance in secretions of the uterus when it is receptive to blastocyst implantation. Thus, these macromolecules provide protection from infection when it is needed for peri-implantation development to continue. Second, histone secretion by the uterus beginning about $15 \mathrm{~h}$ before blastocyst implantation could cause the observed suppression of amino acid transport system $\mathrm{B}^{0,+}$ activity in blastocysts in utero. Removal of histones from the implantation chamber at the time motile trophoblasts penetrate the uterine epithelium would reactivate system $\mathrm{B}^{0,+}$ to take up tryptophan. Tryptophan is needed for T-cell proliferation, so its uptake and metabolism by blastocysts would help to prevent their immunologic rejection when they are most vulnerable owing to trophoblast penetration of the uterine epithelium. Because of these possible beneficial actions of extracellular histones, efforts to mitigate histone cytotoxicity in the reproductive tract should be cautious.

\section{AUTHOR CONTRIBUTIONS}

The author confirms being the sole contributor of this work and approved it for publication.

Kothary, V., Doster, R. S., Rogers, L. M., Kirk, L. A., Boyd, K. L., RomanoKeeler, J., et al. (2017). Group B Streptococcus induces neutrophil recruitment to gestational tissues and elaboration of extracellular traps and nutritional immunity. Front. Cell. Infect. Microbiol. 7:19. doi: 10.3389/fcimb.2017.00019

Lefrançais, E., and Looney, M. R. (2017). Neutralizing extracellular histones in acute respiratory distress syndrome: a new role for an endogenous pathway. Am. J. Respir. Crit. Care Med. 196, 122-124. doi: 10.1164/rccm.201701-0095ED

Lindqvist, I., Einarsson, B., Nilsson, O., and Ronquist, G. (1978). The in vivo transport of ${ }^{14} \mathrm{C}$ - $\alpha$-aminoisobuturic acid into mouse blastocysts during activation for implantation. Acta Physiologica 102, 477-483. doi: 10.1111/j.1748-1716.1978.tb06096.x

Mårdh, P. A. (2004). Tubal factor infertility, with special regard to chlamydial salpingitis. Curr. Opin. Infect. Dis. 17, 49-52. doi: 10.1097/00001432-200402000-00010

Munn, D. H., Zhou, M., Attwood, J. T., Bondarev, I., Conway, S. J., Marshall, B., et al. (1998). Prevention of allogeneic fetal rejection by tryptophan catabolism. Science 281, 1191-1193. doi: 10.1126/science.281.5380.1191

Nilsson, B. O., and Ljung, L. (1985). X-ray micro analyses of cations (Na, K, Ca) and anions $(\mathrm{S}, \mathrm{P}, \mathrm{Cl})$ in uterine secretions during blastocyst implantation in the rat. J. Exp. Zool. 234, 415-421. doi: 10.1002/jez.1402340309

Papayannopoulos, V. (in press). Neutrophil extracellular traps in immunity and disease. Nat. Rev. Immunol. doi: 10.1038/nri.2017.105

Parseghian, M. H., and Luhrs, K. A. (2006). Beyond the walls of the nucleus: the role of histones in cellular signaling and innate immunity. Biochem. Cell Biol. 84, 589-595. doi: 10.1139/o06-082

Silk, E., Zhao, H., Weng, H., and Ma, D. (2017). The role of extracellular histone in organ injury. Cell Death Dis. 8:e2812. doi: 10.1038/cddis.2017.52

Simon, P., Bäumner, S., Busch, O., Röhrich, R., Kaese, M., Richterich, P., et al. (2013). Polysialic acid is present in mammalian semen as a posttranslational modification of the neural cell adhesion molecule NCAM and the polysialyltransferase ST8SiaII. J. Biol. Chem. 288, 18825-18833. doi: $10.1074 /$ jbc.M113.451112

Smith, J. A., Martin, L., King, R. J. B., and Vértes, M. (1970). Effects of oestradiol$17 \beta$ and progesterone on total and nuclear-protein synthesis in epithelial and stromal tissues of the mouse uterus, and of progesterone on the ability of these tissues to bind oestradiol-17ß. Biochem. J. 119, 773-784. doi: 10.1042/bj1190773 
Van Winkle, L. J. (1977). Low $\mathrm{Na}^{+}$concentration: a factor contributing to diminished uptake and incorporation of amino acids by diapausing mouse blastocysts?. J. Exp. Zool. 202, 275-281. doi: 10.1002/jez.1402020218

Van Winkle, L. J. (1993). Endogenous amino acid transport systems and expression of mammalian amino acid transport proteins in Xenopus oocytes. Biochim. Biophys. Acta 1154, 157-172. doi: 10.1016/0304-4157(93)90009-D

Van Winkle, L. J., and Campione, A. L. (1987). Development of amino acid transport system $\mathrm{B}^{0,+}$ in mouse blastocysts. Biochim. Biophys. Acta 925, 164-174. doi: 10.1016/0304-4165(87)90106-1

Van Winkle, L. J., Campione, A. L., and Webster, D. P. (1983). Sodium ion concentrations in uterine flushings from "implanting" and "delayed implanting” mice. J. Exp. Zool. 226, 321-324. doi: 10.1002/jez.1402260219

Van Winkle, L. J., Tesch, J. K., Shah, A., and Campione, A. L. (2006). System B B $^{0,+}$ amino acid transport regulates the penetration stage of blastocyst implantation with possible long-term developmental consequences through adulthood. Hum. Reprod. Update 12, 145-157. doi: 10.1093/humupd/dmi044

Wiesenfeld, H. C., Hillier, S. L., Krohn, M. A., Amortegui, A. J., Heine, R. P., Landers, D. V., et al. (2002). Lower genital tract infection and endometritis: insight into subclinical pelvic inflammatory disease. Obstet. Gynecol. 100, 456-463. doi: 10.1097/00006250-200209000-00011

Witkin, S. S., Linhares, I. M., Bongiovanni, A. M., Herway, C., and Skupski, D. (2011). Unique alterations in infection-induced immune activation during pregnancy. BJOG 118, 145-153. doi: 10.1111/j.1471-0528.2010.02773.x
Wygrecka, M., Kosanovic, D., Wujak, L., Reppe, K., Henneke, I., Frey, H., et al. (2017). Antihistone properties of C1 esterase inhibitor protect against lung injury. Am. J. Respir. Crit. Care Med. 196, 186-199. doi: $10.1164 / \mathrm{rccm} .201604-0712 \mathrm{OC}$

Xu, J., Zhang, X., Pelayo, R., Monestier, M., Ammollo, C. T., Semeraro, F., et al. (2009). Extracellular histones are major mediators of death in sepsis. Nat. Med. 15, 1318-1321. doi: 10.1038/nm.2053

Yang, R., Zou, X., Tenhunen, J., and Tønnessen, T. I. (2017). HMGB1 and extracellular histones significantly contribute to systemic inflammation and multiple organ failure in acute liver failure. Mediators Inflamm. 2017, 1-6. doi: $10.1155 / 2017 / 5928078$

Conflict of Interest Statement: The author declares that the research was conducted in the absence of any commercial or financial relationships that could be construed as a potential conflict of interest.

Copyright (c) 2017 Van Winkle. This is an open-access article distributed under the terms of the Creative Commons Attribution License (CC BY). The use, distribution or reproduction in other forums is permitted, provided the original author(s) or licensor are credited and that the original publication in this journal is cited, in accordance with accepted academic practice. No use, distribution or reproduction is permitted which does not comply with these terms. 